\title{
Mentor Texts and the Coding of Academic Writing Structures: A Functional Approach
}

\author{
El uso de textos modelo y la codificación de estructuras de la \\ escritura académica: un abordaje funcional ${ }^{*}$
}

\author{
Wilder Yesid Escobar Alméciga \\ escobarwilder@unbosque.edu.co \\ Reid Evans \\ Evansreid@unbosque.edu.co \\ Universidad El Bosque, Colombia
}

The purpose of the present pedagogical experience was to address the English language writing needs of university-level students pursuing a degree in bilingual education with an emphasis in the teaching of English. Using mentor texts and coding academic writing structures, an instructional design was developed to directly address the shortcomings presented through a triangulated needs analysis. Through promoting awareness of international standards of writing as well as fostering an understanding of the inherent structures of academic texts, a methodology intended to increase academic writing proficiency was explored. The study suggests that mentor texts and the coding of academic writing structures can have a positive impact on the production of students' academic writing.

Key words: Academic writing, communities of practice, mentor texts, metacognition, second-language literacy, text coding

La presente experiencia pedagógica tuvo como objetivo atender las necesidades del proceso de escritura en inglés como lengua extranjera de estudiantes universitarios del programa de Educación Bilingüe con énfasis en la enseñanza del inglés. Por medio de textos modelo y de la codificación de estructuras de escritura académica se desarrolló un plan de instrucción buscando abordar las falencias develadas en la triangulación del análisis de necesidades. Implementando textos modelo que promovieran la concientización de estándares internacionales de escritura y el entendimiento de las funciones es-

* Received: January 10, 2014. Accepted: August 27, 2014.

How to cite this article (APA $6^{\text {th }}$ ed.):

Escobar Alméciga, W. Y., \& Evans, R. (2014). Mentor texts and the coding of academic writing structures: A functional approach. HOW, A Colombian Journal for Teachers of English, 21(2), 94-111. 
tructurales de textos académicos, se exploró una metodología que pretendía optimizar las competencias de estudiantes al enfrentarse a tareas de escritura académica. El estudio sugiere que la implantación de textos modelo y la codificación de estructuras de la escritura académica puede llegar a tener un impacto positivo en la producción académica escrita de los estudiantes.

Palabras clave: alfabetismo en la segunda lengua, codificación de textos, comunidades de práctica, escritura académica, meta cognición, textos modelo

\section{Introduction}

The ever-evolving pursuit of academic, cultural, and commercial exchange on a global level demands a more diversified and higher level of proficiency in English as a foreign language (EFL). Such proficiency, therefore, must not be limited to the learning of day-to-day language interactions, but requires intellectual levels of communication to enable participation in numerous social realms of universal ${ }^{1}$ communities of practice. $^{2}$ Political and environmental decision making on a global scale, for example, affects all nations and involves countless communities requiring the use of a common language, which, the last few decades, has been English, in order to achieve understanding and consensus. Likewise, academic and professional mobility to North American, European, and even Asian countries demands a scholarly command of English for participants to successfully function while immersed in diverse English-speaking contexts. Moreover, within the field of education, English is essential to establish and exchange internationally the locally-constituted body of knowledge. This suggests a need for Colombian citizens to attain a superior command of English as a foreign language so that they may participate more fully in the complex international academic community.

However, Escobar Alméciga and Gómez Lobatón (2010) assert that language is culturally-bound; communities speak about their lived experiences and, in turn, such experiences shape the form of language. Likewise, Munby (1977) argues that the development of communicative competence does not rely solely on the learning of grammar rules, but that there are sociocultural rules of language use, often understated in English language teaching, without which such grammar becomes futile. He also advocates for the

1 The notion community of practice was developed by Jean Lave and Etienne Wenger (Lave \& Wenger 1991; Wenger, 2000) as the basis of a social theory of learning and described as a collection of people who engage on an ongoing basis in some common endeavor: a bowling team, a book club, a friendship group, a crack house, a nuclear family, a church congregation.

2 "Theories conceive of practice as embodied materially mediated arrays of human activity centrally organized around practical understanding” (Schatzki, 2001, p. 11). However, Sharratt and Usoro (2003) suggest that these communities of practice are no longer local or restricted by geographical conditions but rather mediated by technology; they could potentially transcend country frontiers to become universal. 
importance of exploring ways in which to expose language learners to these sociocultural rules of language use. In other words, there are culturally-defined aspects of both spoken and written forms of language such as genre, style, syntax, collocations and so on which are constructed, defined, shaped, and determined by the social use of the language, which initially suggests an approach to "language and communication in integral relation to social contexts and functions" (Hymes, 1964, p. 8).

To further illustrate the problem, students completing their studies in the undergraduate teacher accreditation program at a private university in Bogotá are required to complete a culminating monograph in academic English to account for a pedagogically-innovative classroom project encompassing five main sections (chapters): an introductory chapter, theoretical framework, research design, analysis and findings, and conclusions. Each of these sections is strategically written as an expository text composed of an introduction, body, and conclusion. These later macro structures, in turn, employ other micro structures to realize specific linguistic functions. This is carried out in a three-semester course whose objectives appeal to the development of the following research competences: to encourage innovative and evolved teaching practices in pre-service teachers through research; to put into use the academic writing skills acquired in prerequisite academic writing classes; to enhance writing skills and systematization techniques, and to foster collaborative work among group members. However, examination of the resulting research monographs has revealed great limitations in three main writing-related areas: organization and cohesion of text, idea development and content clarity, and sentence fluency as defined by Diederich (1974). His framework elaborates on the development of such elements so that teachers of English can discuss the qualities and flaws of the writing that they are assessing. Idea development and content clarity, which Diederich treats together, are said to be adequate when the student's "points are clearly related to the topic and to the main idea or impression he is trying to convey [and] no necessary points are overlooked" (Diederich, 1974, p. 55). It is also suggested that appropriate sentence fluency is achieved when students "write sentences in many forms to fit the mood, to make the meaning clear, to flow into the surrounding sentences, or to make a point stand out" (Diederich, 1974, p. 91).

The abovementioned shortcomings impact the outcomes of the students' projects in terms of time, comprehension, and the dissemination of results within the academic community. In other words, the time that should be devoted to acquiring research competences is used for teaching academic writing structures. Furthermore, potentially valuable concepts are not written comprehensibly and may fail to thoroughly communicate ideas to the reader. ${ }^{3}$ Finally,

3 For further reading on the direct relationship between proficiency and academic and professional performance, see Hymes (1972). 
the positioning of relevant, researchable ideas in local and international academic communities of practice is restricted by the students' low writing proficiency.

The present article, thus, communicates a pedagogical experience aimed at remediating such a situation which has equally been identified by other Colombian researchers positioning the issue at national and international levels of relevance (Correa, 2009; Mendoza López, 2005). Such research suggests that students do not attain the appropriate literacy competences in high school to function in postsecondary EFL academic contexts; therefore, universities are left with the task of mitigating the shortcomings of high school writing education. Similarly, Mendoza López (2005) argues that academic writing instruction should be approached as a communicative process which involves a set of strategies such as organization, brainstorming, drafting, and revising, among others. Writing in EFL is typically associated with prescriptive and mechanical procedures (Escobar Alméciga, 2013a) such as cloze passages, matching exercises, word-count standards, and so on. In direct opposition to such views, the present methodology focuses specifically on modeling and developing language functions given that

language consists of both structures and functions. Structures include words, sounds, morphemes, parts of speech, sentence structures, and so forth. Functions refer to the way that the learning system acquires the meaning or thoughts of cognition for social development ... [This] system functions more holistically than the simple addition of structures and the result is greater than the sum of the parts" (Arwood, 2010, p. 34).

While nurturing the relationship between reading and writing skills through the use of mentor texts and the coding of text structures, this pedagogical implementation also seeks to raise student awareness of what $\mathrm{s} / \mathrm{he}$ is doing or needs to be doing in a given section or with a specific structure to achieve meaningful, coherent, and accurate expression of his/her thoughts. This includes exploring ways in which an introduction of a research design section meaningfully and accurately provides background information on the type of study, or how the conclusion of the theoretical framework recapitulates salient points from the concepts addressed and so forth while studying language functions across structures and sections.

\section{Literature Review}

\section{Communities of Practice}

While the range of academic journals within the global academic community is quite vast, the opportunities for publication for non-native speakers of English may be somewhat discouraging. While multiple opportunities for publication do exist within the small, compartmentalized sectors of the academic community, access to authorship in top publications is somewhat limited. This idea, among others, has been the focus of Canagarajah 
(2010), who suggests a need for an increase in publications that fall outside of the traditional geographic domains as research knowledge is highly contextual and may not apply in all educational environments. Canagarajah (2010) contends that the vast majority of published knowledge appears in geographically-limited, Western publications, a fact that may severely limit access to, in what he terms, peripheral authors (Canagarajah, 2010). Perhaps more importantly, he continues by suggesting that teaching and learning styles vary amongst world communities, yet the knowledge presented in mainstream journals may not be representative of that which each individual community requires to best develop its educational practices.

The concern expressed in Canagarajah's arguments becomes even more disconcerting as we consider that, due to the lack of geographical sensitivity, the strategies and methods portrayed in major academic journals may be somewhat forced upon certain communities with unique educational and cultural needs (Canagarajah, 2010). Specifically within the Colombian context, this notion serves only to extend the necessity for publication as the distinctive needs of the Colombian educational system may not receive the necessary consideration in the highly-compartmentalized mainstream publications. An increase in the dissemination of Colombian-specific scholarly knowledge, particularly within the field of bilingual education, may prove doubly beneficial as the unique needs of the society can be developed in a more intimate manner.

In order to achieve these ends, students must be granted full-access (or the closest approximation) to the activities of the community. It is through participation and not instruction, argues Canagarajah (2002), that students assimilate the practices of the community. In the classroom, this is attained primarily through tasks which possess both "functionality and meaning in relation to the activities of that circle [so that students] produce written texts that make a valid contribution to knowledge" (Canagarajah, 2002, p. 31). Furthermore, interaction and exposure to the community, particularly with the form and function of language, has been demonstrated to develop awareness and a certain level of ease, per se, on behalf of the students which may assist in their assimilation into the academic community (Van de Poel \& Gasiorek, 2012).

In the Colombian context, specifically, a facilitated assimilation into the academic community equates to greater opportunities for the dissemination of culturally-specific knowledge, a notion which, assuredly, will foster the development of appropriate theory and practice by those already in the field. This is precisely the goal of publication within the Colombian academic community which "attempts to maintain a professional space for teacher educators, new teachers, researchers, innovators, and grassroots teachers committed to making their work public" (Cárdenas, 2013, p. 10). These diverse opportunities to share one's voice and ideas will greatly contribute to the advancement of education within this specific community. 


\section{L2 Writing Proficiency}

The need for proficiency in academic English for second-language users has been clearly delineated in literature, both for the use in EFL-specific disciplines as well as those in other academic concentrations (Kroll, 2003; Todd, 2009; Wang \& Bakken, 2004). It is often a need of academic writing courses to meet the demands of developing second-language users as they attempt to produce written discourse which complies with the standards and conventions within a specific scholarly community (Lewin, Fine, \& Young, 2001).

Undergraduate language courses within the field of EFL, however, are often unsuccessful in meeting the demands of the students and, therefore, their subsequent production fails to meet the standards upheld by such communities (Correa, 2009; Wang \& Bakken, 2004). At the university level, the second-language learner requires a developmentally-appropriate program which addresses the professional goals of the student (Friend, 1973; Kroll, 2003; Perin, 2013). This notion holds particularly true within the area of academic writing as second-language English users may not be fully aware of their writing deficiencies and may not possess the necessary knowledge of writing standards (Wang \& Bakken, 2004).

The concept of academic unpreparedness in relation to students' literacy skills was explored by Perin (2013) who, although working specifically within the US community, contends that low English language proficiency directly contributes to poor performance in the areas of reading and writing. The author suggests, in an attempt to remedy poor literacy skills, that classroom instruction adopt an approach which seeks to combine the components of both reading and writing through the use of authentic materials that directly relate to the academic needs and interests of the students (Perin, 2013). Finally, both Perin (2013) and Perin, Bork, Peverly, Mason, and Vaselewski (2012) posit that the explicit incorporation of literacy strategies may foster the reading and writing skills of students in the postsecondary curriculum.

Furthermore, the linguistic and cultural background of the target audience must be taken into consideration as "composing text means logically constructing and arranging discourse forms into particular culturally conditional patterns expected by target language readers" (Silva \& Leki, 2004, p. 5). Thus, writers must learn to communicate successfully within the community specific to their academic disciplines (Canagarajah, 2002; Van de Poel \& Gasiorek, 2012), as well as to adhere to the requirements necessary for publication in academic journals (Wang \& Bakken, 2004).

Much research has explored the second language (L2) writing paradigm through various lenses including the use of corpus technology (Yoon, 2005), collaborative, project-based academic writing (Kessler, Bikowski, \& Boggs, 2012), process-based writing (Mendoza López, 2005), the enhancement of self-efficacy (Van de Poel \& Gasiorek, 2012), and the role of metacognition (Negretti, 2010, 2012; O’Brien-Moran \& Soiferman, 2010), among others. 
Such research provides valuable insights into second-language academic writing development and affirms a need for specific work within the context of literacy instruction. The International Reading Association and the National Council of Teachers of English (IRA/NCTE) have developed literacy standards according to which classroom instructional practices should be developed in order to provide students with the skills and resources for academic success by building on students' literacy abilities. Such standards call for the incorporation of a multitude of literacy skills and practices into classroom activities so that students may "find their own voices and realize that writing gives them new communicative powers" (IRA/NCTE, 1996, p. 14). Perhaps this is most relevant in Standard 6 which suggests that students apply specific knowledge to the structure and conventions of language with regard to the purpose of each genre (IRA/NCTE, 1996).

Finally, Mahecha, Urrego, and Lozano (2011) draw a comprehensible relationship between writing and reading comprehension introducing the strategy of text coding in order to guide the comprehension of specific academic texts. Although this research focused specifically on the skill of reading comprehension, assigning predetermined colors to specific parts of texts may produce similar awareness when applied in the writing classroom.

\section{Mentor Texts}

One particularly adequate method of addressing poor writing comes in the form of the mentor text, or a piece of writing that is observed and analyzed so that students may attempt to imitate one or more linguistic functions. The concept of the mentor text is driven by the notion that good writing spawns good writers as writers emulate and incorporate that which they observe in well-written texts (Cairney, 1995; Graham \& Perin, 2007; Mendez Newman, 2012; Oczkus, 2012; Zuidema, 2012). As such, the use of mentor texts may seek to remedy writing difficulties within various aspects of text production including structure, genre, word choice, voice, content clarity, idea development, and so forth (Oczkus, 2012; Robb, 2011). While such a concept has been extensively applied in the literacy classroom with the writing of fiction (e.g., Corden, 2007; Mendez Newman, 2012), the adoption and application of mentor texts can be transferred to the academic writing context as well (Silva \& Leki, 2004; Wingate, 2012). The use of such texts aligns with current trends in the L 2 writing paradigm as texts in the target language are often brought to the foreground of literacy instruction so that exemplary writing can be examined and, it is hoped, replicated in the students' work (Silva \& Leki, 2004). Conversely, mentor texts may serve as an illustration of poor writing to increase student awareness of undesirable writing patterns. Language instructors may also choose to incorporate poor writing samples for the purpose of analysis and review so that students may become aware of the common errors which often hinder the readability and coherence of texts. 
Academic writing, as opposed to its fictional kin, requires specific development on behalf of the writer so that writing production approximates the general, culturally-accepted norms within the academic community. Although academic writing is not steadfast in its structure by any means, the academic community has grown accustomed to developing writing in such a way that the communication of concepts and ideas is facilitated. Such a notion must occupy a central position in instruction particularly if the goal of writing is publication at the national or international level. It is imperative, therefore, that students of academic writing become familiar with the structure and tone of such written production and learn to replicate that which members of the academic community do while writing (Correa, 2009). Mentor texts which appropriately display discourse within the specific academic community work to expose students to that which is generally considered to be respectable and prolific in terms of writing structure and style. The effects of the exposure to and the analysis of such texts, it is suggested, may contribute to an increase in student comfort and confidence when writing (Van de Poel \& Gasiorek, 2012).

\section{Metacognition and the Writing Process}

Providing students with explicit models of good writing while encouraging observation, engagement, and assimilation of linguistic patterns, on the one hand, and guiding a strategic analysis about the language patterns which made low quality writings poor, on the other, may promote metacognitive awareness of the text dynamics examined in such writing improving the language choices made by writers as they construct texts (Corden, 2007). Furthermore, specific training in metacognition "allows novice writers to begin to understand the effects that thinking about writing has on the writing process" (O'Brien-Moran \& Soiferman, 2010, p. 5). An awareness of one's language choices combined with a heightened disposition to overtly thinking about one's writing process, consequently, should result in a greater ability to self-regulate and self-evaluate throughout the writing process (Negretti, 2010, 2012).

An ability to comprehend, monitor, and reflect upon one's thoughts is the essence of metacognition. A student aware of the metacognitive area is said to be able to monitor the cognitive decisions that he or she makes and assess the effectiveness of such decisions (Thiede, 2002). This is particularly salient in the academic writing process as the decisions made by writers often directly impact comprehension on behalf of the reader. Thus, it is essential that students not only possess knowledge regarding writing style and structure, but that they also possess the ability to continually reassess their language choices. In the area of academic writing, Negretti (2012) suggests that such awareness must be based upon the understanding of the communicative and resolute nature of scholarly texts.

The incorporation of mentor texts into the language classroom, it is suggested, is pivotal in developing the metacognitive awareness that is indispensable to appropriate academic 
writing. By demonstrating and engaging students in the understanding of well-written scholarly material, students may begin to develop a greater awareness of the accepted structure in areas such as idea development, content clarity, and sentence fluency as defined by Diederich (1974).

\section{Implementation}

Writing in a second language presents countless challenges not only to university students in the course of their undergraduate studies, but also to in-service professionals and teachers particularly when trying to accomplish academic tasks. In this respect, the undergraduate teacher education program where this project was implemented includes a research component which requires that students identify and characterize a problem and design a specific plan of action which may potentially mitigate the impact of such an issue. Since this pedagogical project is written in academic English, it not only seeks to develop research-related skills, but strives also to improve academic writing competences for international communication with the goal of publishing students' work as a way to contribute to the building of their professional resumes.

Previously-analyzed examples of the written reports from such projects demonstrated substantial inadequacies in students' writing, specifically in the areas of text organization, sentence fluency, and content clarity. Before the instructional design of this project was developed, students' written production was evaluated from three different angles: the student manuscripts were analyzed by the class professor, by a native-speaking proofreader, and via a student survey designed to inquire as to the students' perceptions regarding their own shortcomings when writing for such an academic purpose. The assessments of the learners' texts revealed the specific weaknesses mentioned above and, as such, these shortcomings were incorporated as the focus of instruction.

The aforementioned factors motivated and directed the design and implementation of the pedagogical strategy at hand, which was guided by the following objectives:

- To expose students to standard levels of international academic writing.

- To encourage students to recognize the structures of academic writing to foster writing proficiency through the use of mentor texts and the coding of academic writing structures.

- To promote the meta-awareness of students' writing competences.

- To promote the awareness of the role of writing in the professional setting. 


\section{Process and Procedure}

The project was carried out in three stages including problem identification and characterization, the design and implementation of a plan of action aimed at mitigating the difficulties, and finally, the report and diffusion of the results. Cyclical interventions which focused on the three main writing areas mentioned above were designed, evaluated, and continually improved throughout the implementation.

Prior to implementation, high-quality mentor texts were chosen that demonstrated appropriate text organization, included fluent, comprehensible language use and clearly and accurately articulated content. With these components in mind, the researchers reviewed numerous academic texts and ultimately selected exemplary writing which would be used during the implementation of the lessons. A total of 17 mentor texts was chosen and designated for use within the three lessons. In order to assure consistency of topics and terminology, the researchers chose academic research articles which fell within the general framework of applied linguistics.

On the first day of implementation, text organization was the focus of instruction and began with the most basic components of expository text structure-introduction, body, and conclusion-which, in turn, delineated the structure of each of the sections in the manuscript. These three macrostructures were chosen as a starting point to avoid the assumption that all students would be familiar with them. As such, the first mentor texts used in the lesson were divided into introductions, body paragraphs, and conclusions, and were distributed to the students. Working in groups, the students were asked to examine the text that they had received and to decide which macrostructure was portrayed based on the vocabulary contained within. The researchers then elicited responses from the students who defended their answers with examples of the words or phrases which indicated that the text was an introduction, body paragraph, or a conclusion (see Appendix).

Next, the researchers focused specifically on the introduction and the linguistic functions that its microstructures should accomplish within expository texts. Students were provided with examples of well-written introductions and were asked to identify the background information, the thesis statement, and the information pertaining to the organization of the section. Selecting the information to include within an introduction, as well as the amount and quality of background information to successfully position an argument, often presents difficulty for those attempting to write academic texts (Swales, 1990). Therefore, the components mentioned above were deemed essential for the writing of the academic introduction as they served to approach the objectives of an introduction as proposed by Lewin et al. (2001). The first section includes background information informing the reader of the topic to be addressed, citing previous notions highlighting the importance of the discussion at hand thus claiming relevance in the field. Next, the thesis 
statement $t^{4}$ was described as the stance or position regarding the purpose of the topic being addressed and clarifying the main objective of the section. Finally, students were asked to examine the components of the selected introductions which were specifically related to the organization of the section. Such components hinted at the contents that were to be elucidated, as well as the conclusions that were to be drawn from the text.

It was at this point that the idea of text coding was introduced to the students. Demonstrated first with projected examples via PowerPoint, students were asked to color code each section using red for background information, green for the thesis statement, and blue for the components related to organization. Once the students had worked to identify and color code these components, their responses were shared with the class and compared to examples that had been previously prepared by the instructor.

To conclude the first lesson, the structure of the thesis statement was explored and mentor texts were again used to provide students with examples of coherent, well-written thesis statements. The researchers directed students' attention to the structure of the thesis statement and the students identified both the topic and the controlling idea in the examples provided. The role of each was then discussed in light of the examples provided.

The second lesson was designed to shed light on the idea of development and structure within body paragraphs. Students were first introduced to the idea of topic and concluding sentences within body paragraphs and reviewed various examples of preselected mentor texts which appropriately accomplished these functions. Prior to implementation, several texts were evaluated by the instructors following the guidelines set forth by Diederich (1974) and texts were selected which demonstrated coherence between the topic and concluding sentences as well as provided ample supporting details to corroborate the topic of each paragraph. Text coding for paragraphs was then introduced and students were asked to code the topic and concluding sentences in blue and the supporting details of the paragraphs in black. Coding the topic and concluding sentences in blue facilitated direct associations between the information contained in those components of the paragraph as well as highlighted the direct relation to the blue section of the introduction which delineated the organization of the paper. As such, students could revise the information that they chose to include in a particular section of their project and adjust such content so that it aligned with the purpose of the section being written and was relevant to the topic.

4 While Lewin et al. (2001) do not explicitly mention the thesis statement, they do describe in move 3 the necessity to define the purpose of the study as well as the use of what they refer to as the hypothesis. For the sake of simplicity when working with undergraduate students, we chose to refer to this element simply as the thesis statement. 
To conclude the second lesson while reinforcing the concept of supporting details, students were provided with examples of body paragraphs whose supporting details had been eliminated leaving the topic and concluding sentences exclusively. The students were then asked to read these sentences and work together in groups to determine appropriate facts, anecdotes, quotations, or evidence from investigation that would accurately support the main idea of the paragraph. This information was then shared and discussed with the class as a whole.

Finally, the third lesson of the implementation was created to address the concept of sentence fluency as a means of increasing text readability. Based upon the criteria for appropriate sentence fluency (Diederich, 1974), mentor texts were employed which demonstrated a variety of sentence beginnings and lengths, diversity in transitions and conjunctions, and ultimately served to invite natural, prosodic reading. To promote awareness of these concepts, students examined text samples and analyzed the use of such in the examples provided.

In other words, our functional approach to text analysis required students to review a number of texts and initially isolate their main linguistic structures in order to recognize their communicative form and function. Subsequently, they were expected to identify, select, and semantically categorize lexis according to the particular communicative task being accomplished constituting high-quality expository texts. Finally, the students were guided through an examination of content correspondence amongst introductions, body paragraphs, and conclusions which generally ensures the coherence of a particular text. All of these processes were then mirrored by an examination of texts which failed to achieve the communicative functions at hand, which distinguished excellent quality writing from poor, and stirred responsiveness on the type of language configurations that aids in achieving functions and those that hinder it.

Once the students had participated in the three lessons, they were asked to incorporate language patterns in their fulfilment of the communicative functions and implement the skills and principles acquired while reviewing and correcting their personal academic writing. Not only did the students attempt to incorporate various aspects of sentence fluency, create coherence within their body paragraphs, and appropriately develop their introductions, they were also asked to color code the respective parts of their academic writing and analyze such parts based on what they had learned throughout the implementation. This exercise enabled students to internally comprehend their own writing process based on the external exposition of good writing and to consider the shortcomings which may have hindered the comprehensibility and readability of their original works in order to further improve their writing production. Furthermore, once these documents were turned in to the tutor, the color-coded sections were reviewed to determine if they indeed accomplished that which was 
intended in each section and, thus, appropriate feedback was given as the students progressed through the writing process.

\section{Discussion}

Through classroom instruction, which included both superlative as well as poor samples of mentor texts - paired with the coding of text structures - students became aware of the type of information needed in the specific segments of academic texts and their corresponding roles. Additionally, they gained the ability to recycle linguistic resources and developed meta-cognitive skills that yielded self-monitoring, self-revision, and self-correction resulting in papers demonstrating improved organization, coherence, and readability upon the first submission.

By differentiating components through color-coding, students began to recognize the differences between items within corresponding macrostructures. As a result, they learned to distinguish an introduction from a body and a concluding paragraph and drew clear connections between the organization section of the introduction and the corresponding relationship to the body paragraphs, thus promoting cohesiveness. The organization segment of an introduction in any section, for instance, provided the parameters of sequence and content for the topic sentences of the body paragraphs to follow. In the theoretical framework, for example, it delineated the sequence for the conceptual constructs to be addressed in the data analysis for the categories, and so forth. The thesis statement drew clear connections to the questions and objectives and its reciprocally corresponding information. In other words, the learners gained knowledge on what they needed to accomplish, and in what manner they could achieve such a goal.

In addition, this strategy brought about an unexpected asset to the evaluation of the texts on behalf of the instructor. The assessment of color-coded structures proved highly convenient and time efficient as the colors precisely indicated when and where the learner attempted to fulfill a linguistic function, thus providing points of reference and conceptual information for precise and comprehensible feedback.

In sum, incorporating mentor texts and text coding into the teaching of academic writing isolates the functional components of academic texts, highlights and emphasizes the elements that must be included while modeling and guiding the linguistic functions to be achieved. As such, it generates and develops metacognitive skills that trigger self-monitoring, self-revision, and self-correction fostering independent learners. In addition to separating the texts into their communicative functions, the use of mentor texts and text coding also promotes clear associations among them, leading to coherence and achieving high-quality writing products which reflect analysis and synthesis in their content and writing. 


\section{Conclusions}

The incorporation of mentor texts and text coding into the foreign-language writing classroom proved successful on many levels. Student writing demonstrated significant improvement and instructor feedback was enhanced via the guidance of coded structures. We would be remiss to say, however, that the present methodology was without limitation. As writing development, particularly within the academic realm, is a progressive process, time limitations somewhat confined the extent to which remediation was implemented. Consequently, further research is warranted into other significant aspects of academic writing such as word choice, voice, conventions, and perhaps even the application of the APA style. Such investigation may help to amplify the academic writing instructional paradigm to foster further noteworthy production.

In line with the specified objectives, the present strategy initiated a process that resulted in an increased publication on behalf of the students with several research projects being accepted in academic publications and conference memoirs (for examples, see Achury \& Ramírez, 2013; Escobar Alméciga, 2013b; Escobar Alméciga \& Castañeda-Peña, forthcoming). Such accomplishments have contributed significantly to the dissemination of locally-constituted knowledge. Additionally, several invitations were extended to the authors to present the aforesaid methodology in Colombia as well as in the United States, further contributing to the internationalization of the Colombian academic community.

\section{References}

Achury, J. K., \& Ramírez, D. C. (2013). Analysis of social constructions in interaction of EFL learners through the lens of gender. Memorias XIX Congreso Institucional de Investigaciones. Bogotá, CO: Editorial Universidad El Bosque.

Arwood, E. (2010). Language function: An introduction to pragmatic assessment and intervention for higher order thinking and better literacy. London, UK: Jessica Kingsley Publishers.

Bu, J. (2012). A study of relationships between L1 pragmatic transfer and L2 proficiency. English Language Teaching, 5(1), 32-43.

Cairney, T. H. (1995). Pathways to literacy. London, UK: Continuum International Publishing Group.

Canagarajah, S. (2002). Multilingual writers and the academic community: Towards a critical relationship. Journal of English for Academic Purposes, 1(1), 29-44.

Canagarajah, S. (2010). Internationalizing knowledge construction and dissemination. Modern Language Journal, 94(4), 661-664.

Cárdenas, M. L. (2013). Editorial. PROFILE Issues in Teachers' Professional Development, 15(1), 7-10.

Corden, R. (2007). Developing reading-writing connections: The impact of explicit instruction of literary devices on the quality of children's narrative writing. Journal of Research in Childhood Education, 21(3), 269-289. 
Correa, D. (2009). Exploring academic writing and voice in ESL writing. Íkala, Revista de Lenguajey Cultura, 14(21), 103-132.

Diederich, P. B. (1974). Measuring growth in English. Urbana, IL: National Council of Teachers of English.

Escobar Alméciga, W. Y. (2013a). Identity-forming discourses: A critical discourse analysis on policy making processes concerning English language teaching in Colombia. PROFILE Issues in Teachers' Professional Development, 15(1), 45-60.

Escobar Alméciga, W. Y. (2013b). Social research applied to English language teaching in Colombian contexts: Theory and methods. Bogotá, CO: Editorial Universidad El Bosque.

Escobar Alméciga, W. Y., \& Castañeda-Peña, H. (In print). Discourse analysis applied to English language teaching in Colombian contexts: Theory and methods. Bogotá, CO: Editorial Universidad El Bosque.

Escobar Alméciba, W. Y., \& Gómez Lobatón, J. C. (2010). Silenced fighters: Identity, language and thought of the Nasa people in bilingual contexts of Colombia. PROFILE Issues in Teachers' Professional Development, 12(2), 125-140.

Friend, J. (1973). College English for the preprofessional or graduate student of EFL. College Composition and Communication, 24(2), 210-213.

Graham, S., \& Perin, D. (2007). Writing next: Effective strategies to improve writing of adolescents in middle and high schools - A report to Carnegie Corporation of New York. Washington, DC: Alliance for Excellent Education.

Hymes, D. (1964). Introduction: Toward ethnographies of communication. American Anthropologist, $66(6), 1-34$.

Hymes, D. (1972). On communicative competence. In J. Pride \& J. Holmes, (Eds.), Sociolinguistics: Selected Readings (pp. 269-293). Harmondsworth, UK: Penguin.

International Reading Association/National Council of Teachers of English. (1996). Standards for the English Language Arts. USA: International Reading Association/National Council of Teachers of English.

Kessler, G., Bikowski, D., \& Boggs, J. (2012). Collaborative writing among second language learners in academic web-based projects. Language Learning \& Technology, 16(1), 91-109.

Kroll, B. (2003). Exploring the dynamics of second language writing. Cambridge, UK: Cambridge University Press.

Lave, J., \& Wenger, E. (1991). Situated learning: Legitimate peripheral participation. Cambridge, UK: Cambridge University Press.

Lewin, B. A., Fine, J., \& Young, L. (2001). Expository discourse: A genre-based approach to social science research texts. London, UK: Continuum International Publishing Group.

Mahecha, R., Urrego, S., \& Lozano, E. (2011). Improving eleventh graders' reading comprehension through text coding and double entry organizer reading strategies. Profile Issues in Teachers' Professional Development, 13(2), 181-199.

Mendez Newman, B. (2012). Mentor texts and funds of knowledge: Situating writing within our students' worlds. Voices From the Middle, (20)1, 25-30. 
Mendoza López, E. (2005). Current state of the teaching of process writing in EFL classes: An observational study in the last two years of secondary school. PROFILE Issues in Teachers' Professional Development, 6(1), 23-36.

Munby, J. (1977). Applying sociocultural variables in the specification of communicative competence. In M. Saville Troike (Ed.), Linguistics and anthropology (pp. 231-247). Washington DC: Georgetown University Press.

Negretti, R. (2010). Metacognitive awareness in developmental writing students. Dissertation Abstracts International, Section A: The Humanities and Social Sciences, 70(7), 2387.

Negretti, R. (2012). Metacognition in student academic writing: A longitudinal study of metacognitive awareness and its relation to task perception, self-regulation, and evaluation of performance. Written Communication, 29(2), 142-179.

O'Brien-Moran, M., \& Soiferman, L. (2010). How an understanding of cognition and metacognition translates into more effective writing instruction. Paper presented at the Annual Education Graduate Student Symposium, Winnipeg, Canada. Retrieved from ERIC database. (ED512209)

Oczkus, L. D. (2012). Best ever literacy survival tips: 72 lessons you can't teach without. Newark, de: International Reading Association.

Perin, D. (2013). Literacy skills among academically underprepared students. Community College Review, 41(2), 118-136.

Perin, D., Bork, R. H., Peverly, S. T., Mason, L. H., \& Vaselewski, M. (2012). A contextualized intervention for community college developmental reading and writing students (CCRC Working Paper, No. 38). New York, NY: Community College Research Center, Teachers College, Columbia University. Retrieved from http://ccrc.tc.columbia.edu/Publication.asp?UID=1007

Robb, L. (2011). Thirteen for thirteen-year-olds. Instructor, 120(6), 36-38.

Schatzki, T. R. (2001). Introduction: Practice theory. In T. R. Schatzki, K. K. Cetina, \& E. von Savigny (Eds.), The practice turn in contemporary theory (pp. 10-23). New York, NY: Routledge.

Sharratt, M., \& Usoro, A. (2003). Understanding knowledge-sharing in online communities of practice. Electronic Journal on Knowledge Management, 1(2), 187-196.

Silva, T., \& Leki, I. (2004). Family matters: The influence of applied linguistics and composition studies on second language writing studies_-Past, present, and future. The Modern Language Journal, 88(1), 1-13.

Swales, J. M. (1990). Genre analysis: English in academic research settings. Cambridge, UK: Cambridge University Press.

Thiede, K. (2002). Learning to learn and metacognition. In J. W. Guthrie (Ed.), Encyclopedia of education (2nd ed., Vol. 4, pp. 1470-1472). New York, NY: Macmillan.

Todd, A. C. (2009). English as a second language instructional approaches for college-level coursework and academic writing: A survey of program directors in institutions of higher education in the United States. Dissertation Abstracts International, Section A: The Humanities and Social Sciences, 69(7), 2636.

Van de Poel, K., \& Gasiorek, J. (2012). Effects of an efficacy-focused approach to academic writing on students' perceptions of themselves as writers. Journal of English for Academic Purposes, 11(4), 294-303. 
Wang, M., \& Bakken, L. L. (2004). An academic writing needs assessment of English-as-a-second-language clinical investigators. Journal of Continuing Education in The Health Professions, 24(3), 181-189.

Wenger, E. (2000). Communities of practice. New York, NY: Cambridge University Press.

Wingate, U. (2012). Using academic literacies and genre-based models for academic writing instruction: A "literacy" journey. Journal of English for Academic Purposes, 11(1), 26-37.

Yoon, H. (2005). An investigation of students' experiences with corpus technology in second language academic writing. Dissertation Abstracts International, Section A: The Humanities and Social Sciences, 66(1), 121.

Zuidema, L. A. (2012). The grammar workshop: Systematic language study in reading and writing contexts. English Journal, 101(5), 63-71.

\section{The Authors}

Wilder Yesid Escobar Alméciga holds a master's degree in applied linguistics to the teaching of English from Universidad Distrital Francisco José de Caldas. He is an associate professor at Universidad El Bosque and his research interests include discourse analysis, identity, and English language teaching. He is currently an active member of the research group Docencia Universitaria Unbosque.

Reid Evans is an assistant professor of EFL and a researcher in the newly founded EDLE research group at Universidad El Bosque in Bogotá, Colombia. He has studied foreign language education and has subsequently earned an M.S. in literacy education from the State University of New York at New Paltz. His previous publications have focused on the topics of linguistic typology, literacy practices, and academic writing in the foreign-language setting. 


\section{Appendix: Instructions and Handouts From Lesson One: Defining Macrostructures}

Distribute the handouts labeled "Lesson One - Essay Macrostructures" to the students. Each student group should receive one handout containing one item from the following: an introduction, body paragraph or conclusion. Encourage students to determine the macrostructure present in their handout. Focus students both on function and linguistic expression to determine the role of each paragraph.

Example of conclusion (italics and underline added to show words indicative of a conclusion):

This paper has studied how L1 pragmatic transfer works on the requestive behaviour of learners at different L2 proficiency levels. Complicated relationships bave been found between L1 pragmatic transfer and L2 proficiency, and it is impossible to say whether L1 pragmatic transfer increases or decreases with L2 proficiency. There are cases in which L1 pragmatic transfer decreases with the increase of L2 proficiency such as the learners' use of direct strategies, lexical and phrasal down graders, imperatives and grounder, and cases in which no clear relationship is found between L1 pragmatic transfer and L2 proficiency in terms of the other request strategies, internal modifiers and external modifiers. Therefore these results provide partial support to negative correlation hypothesis — high proficiency L2 learners are less likely to transfer their native language pragmatic norms since they have enough control over L2.

Taken from $\mathrm{Bu}$ (2012, p. 37) 